\title{
Preliminary Assessment of Newspaper Coverage of Agricultural News in Delta State: A Case Study of the Pointer Newspaper in Delta State, Asaba, Nigeria
}

\author{
Ovwigho B. O. ${ }^{1} \&$ Orogun P. ${ }^{1}$ \\ ${ }^{1}$ Department of Agricultural Economics and Extension, Delta State University Asaba Campus, Asaba, Delta \\ State, Nigeria \\ Correspondence: Ovwigho B. O., Department of Agricultural Economics and Extension, Delta State University \\ Asaba Campus, Asaba, Delta State, Nigeria. E-mail: bishopvwigho@yahoo.com
}

Received: December 21, 2012 Accepted: May 15, 2013 Online Published: May 17, 2013

doi:10.5539/sar.v2n3p101 URL: http://dx.doi.org/10.5539/sar.v2n3p101

\begin{abstract}
The obvious advantage of the newspaper over other methods of disseminating agricultural technologies and information necessitated this exploratory study. The broad objective of the study was to investigate the extent of agricultural news coverage by the pointer newspaper in 2009. The specific objectives were to: ascertain the column inches (space) given to major categories of news by the pointer newspaper in 2009; examine the percentage column inches (space) given to each category of agricultural news by the pointer newspapers in 2009; and. determine the relationship between column inches (space) given to agricultural and other categories of news covered by the pointer newspaper in 2009. Secondary data were obtained from the pointer newspaper main office at Asaba in 2010 for the study. Eight (8) broad categories of news and seven (7) categories of agricultural news were assessed. The column inches for each category of news were measured for each month by use of a measuring tape. It was found that sports were allocated the highest number of column inches with percentage and mean values of $25.61 \%$ and 2010.35 respectively. This was followed by politics $(21.43 \%$; $\mathrm{M}=1682.18)$, religion (11.49\%, M= 901.77), foreign news (10.08\%, $\mathrm{M}=791.63)$, business ( $9.63 \%, \mathrm{M}=760.35)$, entertainment (9.26\%, $\mathrm{M}=727.07)$, education $(8.86 \%, \mathrm{M}=695.47)$ and agriculture $(3.59 \%, \mathrm{M}=282.03)$. Agriculture was the least category of news covered by the pointer news paper. Poultry news $(26.43 \%)$ was the most frequently reported among the categories of agricultural news in 2009. This was followed by forestry and wild life (11.52\%), commentaries (10.96\%), fisheries $(9.90 \%)$, and agronomy (7.17\%). It was found that agriculture news were the least covered by the pointer newspaper in 2009 in spite of the importance of agriculture under the present civilian government. The Pointer newspaper should devote more spaces to agricultural news in order to enhance dissemination of agricultural information to farmers in the state.
\end{abstract}

Keywords: preliminary assessment, newspaper coverage, agricultural news, agricultural extension, agricultural extension methods

\section{Introduction}

Agricultural extension service delivery revolves around three main methods: individual, group and mass media methods. Abbas et al. (2011), Ovwigho and Ifie (2009), Agbamu (2006), Madukwe (2006), Laogun (2005), Rogers (2003), Ekpere and Durant (1986) and Williams et al. (1984) classified agricultural extension methods into individual, group and mass media.

Abbas et al. (2011) gave a two-fold classification of the mass methods of agricultural extension delivery. These were big and small media, and print and electronic media. The big media included complex and costly devices such as educational television, films and computer assisted instructions. The small media included less costly and less complex devices such as radio, tape recorder, film slides, transparencies and visuals. The print media comprises of those forms of printed materials which are distributed on a mass scale. Examples are newspapers, newsletters, books, grey literature, brochures, bulletins, pamphlets, leaflets, handbills, and posters. Electronic mass media include radio and television.

According to Pretty and Vodouche (1997), Chambers (1993), Igbokwe and Enwere (2001), and Korten (1990), the flaws in conventional approaches to rural development as well as agricultural research and extension led to 
rapid expansion in participatory methods and approaches in Asia and Africa. They stated that these methods began with the development of data gathering methods, which came to be known as rapid rural appraisal. They maintained that during the late 1980s, this growing experience was supplemented by drawing upon long established traditions that had put participation, action research, and adult education at the forefront of attempts to emancipate people.

Oladeji (2011), and Olowu and Yahaya (1993) noted that very little or no attention has been given to newspaper coverage of agricultural and rural development activities in Africa with particular reference to Nigeria. They noted that newspapers have a lot of potentials for promoting agricultural and rural development. Abbas et al. (2011) found that newspapers constituted only one percent of the sources of information to farmers in Pakistan The use of newspapers in agricultural extension is particularly useful in creating awareness about new technologies. Okorie and Oyedope (2011), and Okunade (2007) noted that the mass media methods attract attention, provide background information, and stimulate the interest and desire for further information. Ifenkwe (2008), Moemeka (1990), and Carter (1991) stated that the newspaper has more enduring characteristics than the radio and television. Newspapers could be read and re-read at convenience thus allowing fuller and better understanding of the message contents. Newspaper could also be stored away for future references. Okorie and Oyedope (2011), and Singh and Kumah (1977) remarked that newspapers helped to provide information, education, guidance and entertainment to an audience. Ifenkwe (2008) stated that mass media channels (radio, television, computer, newspaper) have revolutionized information delivery to a mass audience simultaneously thereby overcoming problems faced by interpersonal channels. He maintained that the present information and communication age demands that we should rely more on sophisticated information and communication technologies which were capable of reaching a larger audience within a shorter space of time.

A high level of illiteracy and lack of policy thrust for agricultural extension development appear to hinder the use of newspapers in agricultural communication in Africa. However, Mody (1991) noted that, mass media campaign alone was unlikely to eliminate the inequality in rural areas. He remarked that printed media served little purpose in the villages in developing countries.

In essence, the newspapers, when properly employed in the dissemination of agricultural news help to overcome the limitation posed by the individual or interpersonal method of agricultural extension delivery. Costs of using interpersonal channels were high in terms of staff, time and transportation compared to mass media methods. Even in countries with good transportation system; experience has shown that an extension agent could not visit more than 200 farmers regularly (Madukwe, 2006; Van den Ban \& Hawkins, 1996).

According to Ifenkwe (2008) newspaper publication started in Nigeria in 1959. Okorie and Oyedepo (2011) added that there were over 50 privately and government owned daily newspapers and several weekly newspapers in Nigeria. Ifenkwe (2008) further stated that the primary objective of the newspaper was to objectively report news situation or events in all fields of human endeavour. The purpose of the study therefore was to investigate the extent of agricultural news coverage by the Pointer Newspaper. The specific objectives were to:

a) ascertain the amount of space given to different categories of news by the Pointer newspaper in 2009;

b) examine the percentage amount of space given to each category of agricultural news by the Pointer newspaper in 2009; and

c) determine the relationship between the amount of space given to agricultural and other categories of news published by the Pointer newspaper in 2009.

\subsection{Hypothesis}

Ho: There is no significant relationship between column inches allocated to agricultural and other categories of news covered by the Pointer Newspaper.

\subsection{Brief History of the Pointer Newspaper}

The Pointer Newspaper which is owned and managed by the Delta State Government of Nigeria and published by the Delta Printing and Publishing Company Limited Asaba. The company was established vide Edict No. 65, Volume 5 of 1995. The general objective of the newspaper is to disseminate knowledge and give guidance to members of the public on matters of public interest. The specific objectives of the newspaper were to:

1) promote, encourage and stimulate interest in the study of journalism;

2) give publicity to and encourage the arts and crafts of Delta State of Nigeria;

3) undertake and arrange broadcast programme; and 
4) encourage competition and composition of music and literature of all kinds.

The company has seven departments. These include: administration, accounts, editorials, production, circulation, advertisement and work/transport. The company started the publication of the Pointer Newspaper in October 1994. As at 1994, the newspaper was published only on Sundays. By October 1995, it started bi-weekly publication on Thursdays and Sundays. On May 24, 2000, it started as a daily publication and has existed till date.

\section{Materials and Method}

\subsection{Method of Data Collection}

Data were collected from Secondary sources. The Pointer Newspapers constituted the only source of information. The daily and Sunday newspapers from January $1^{\text {st }} 2009$ through December $31^{\text {st }} 2009$ were used for the study. A one year period was considered because of the available fund and enormity of measurement involved in the study. The newspapers were content analysed into 8 categories of news. These were sports, politics, foreign, business, entertainment, religion, education and agriculture. These were the major categories of news covered by most daily newspapers. The agricultural news were content analysed into seven (7) categories namely poultry, agronomy, livestock, forestry and wild life, fisheries, government policies on agriculture, and commentaries. The column inches for the different categories of news were measured by the use of a measuring tape for each day and months of the year (2009). This was because the importance and amount of space allocated to an item in a newspaper was usually measured in economic terms. The column inches from each news items were added up for each month for the purpose of comparison.

\subsection{Method of Data Analysis}

Data were analysed by the use of simple percentage, multiple correlation and analysis of variance. The agricultural news and space allocated were presented in percentages. The average percentage was found for each of the agricultural news for the year 2009. Correlation matrix was used to find the relationships between agricultural and other categories of news. Analysis of Variance was used to test the relationship between the amounts of space given to the major categories of news.

\section{Results and Discussion}

\subsection{Major Categories of News and Coverage}

The amount of space (column inches) allocated to each major category of news for the year 2009 were analysed. The total amount of space, percentage and mean for the eight (8) categories of news were presented in Table 1.

Table 1. Categories of news and column inches allocated per Month in 2009

\begin{tabular}{|c|c|c|c|c|c|c|c|c|c|c|c|c|c|c|c|c|}
\hline \multicolumn{2}{|c|}{ S/N Category } & \multirow{2}{*}{$\frac{\text { Jan }}{2396.2}$} & \multirow{2}{*}{$\frac{\text { Feb }}{2298}$} & \multirow{2}{*}{$\frac{\text { Mar }}{2700.1}$} & \multirow{2}{*}{$\frac{\text { April }}{2631.8}$} & \multirow{2}{*}{$\frac{\text { May }}{2130}$} & \multirow{2}{*}{$\frac{\text { June }}{255.7}$} & \multirow{2}{*}{$\begin{array}{l}\text { July } \\
2698.1\end{array}$} & \multirow{2}{*}{$\frac{\text { Aug }}{2067.3}$} & \multirow{2}{*}{$\frac{\text { Sept }}{2755.1}$} & \multirow{2}{*}{$\frac{\text { Oct }}{209.8}$} & \multirow{2}{*}{$\frac{\text { Nov }}{2104.8}$} & \multirow{2}{*}{$\begin{array}{l}\text { Dec } \\
1989.1\end{array}$} & \multirow{2}{*}{$\begin{array}{l}\text { Total } \\
24124.2\end{array}$} & \multirow{2}{*}{$\begin{array}{l}\% \\
25.61\end{array}$} & \multirow{2}{*}{$\frac{\text { Mean }}{2010.35}$} \\
\hline 1 & Sports & & & & & & & & & & & & & & & \\
\hline 2 & Politics & 836.9 & 650.6 & 939.9 & 989.9 & 2950.5 & 2158 & 2335.5 & 52718.3 & 31163.3 & 1702 & 1638.1 & 1103.1 & 20186.1 & 121.43 & 1682.18 \\
\hline 3 & Foreign & 825.5 & 367 & 833 & 773.1 & 783.3 & 820 & 791 & 789 & 986.5 & 863.7 & 779.5 & 887.9 & 9499.5 & 10.08 & 791.63 \\
\hline 4 & Business & 752.5 & 199.5 & 811 & 808 & 733.8 & 863.8 & 816.3 & 888.7 & 759.5 & 708 & 793.3 & 989.5 & 9123.9 & 9.63 & 760.33 \\
\hline 5 & Entertainment & $\mathrm{t} 724.3$ & 220.3 & 777.1 & 703 & 701.5 & 736 & 711.3 & 733.5 & 800 & 865.3 & 744 & 1008.5 & 8724.8 & 9.26 & 727.07 \\
\hline 6 & Religion & 597.1 & 5051 & 492 & 544.8 & 551.3 & 493 & 508.8 & 506.5 & 397 & 402.3 & 539.5 & 737.9 & 10821.2 & 211.49 & 901.77 \\
\hline 7 & Education & 445.9 & 3859.8 & 491.3 & 238 & 402.3 & 396.7 & 251 & 399.7 & 739 & 410.9 & 401.4 & 309.6 & 8345.6 & 8.86 & 695.47 \\
\hline \multirow[t]{2}{*}{8} & Agriculture & 257.9 & 238 & 298.7 & 256.8 & 213.7 & 333.4 & 225.5 & 316.5 & 211.3 & 261 & 308.4 & 463.1 & 3384.3 & 3.59 & 282.03 \\
\hline & Total & 6836.3 & 10884.2 & 7343.1 & 7945.4 & 48466.4 & 6056.6 & 8337.5 & 58419.5 & $57811 . .7$ & 7312.2 & 7309 & 7488.7 & 94209.6 & 6100 & \\
\hline
\end{tabular}

Table 1 showed that sports news was allocated the highest amount of space in 2009 with a percentage and mean column inches of 25.61 and 2020.35 respectively. This was followed by politics $(21.43 \%, \mathrm{M}=1682.18)$, religion (11.49\%, $\mathrm{M}=901.77)$, foreign news (10.08\%, $\mathrm{M}=991.63)$, business $(9.63 \%, \mathrm{M}=760.35$, entertainment $(9.26 \%$, $\mathrm{M}=727.07)$, education $(8.86 \%, \mathrm{M}=695.47)$ and agriculture (3.59\%, $\mathrm{M}=282.03)$. This showed that agriculture was given the least amount of space by the Pointer newspapers in 2009. This situation did not portray a penchant 
for mass dissemination of agricultural news for the purpose of agricultural development in the state. The Pointer newspaper is the only daily news paper owned by the Delta State Government vested with the responsibilities of agricultural news coverage.

This corroborates the findings of Sitton et al. (2001) and Okorie and Oyedepo (2011) that most newspapers usually neglect agricultural topics and present a narrow picture of the agricultural industry. Wikipedia (2000) stated that attempt to revive agriculture in Nigeria have been unsuccessful due to poor media coverage of agricultural activities and pseudo-legislative backing of agricultural reform programmes.

A significant relationship $(\mathrm{F}=7.55, \mathrm{P}<0.01)$ was found between the amount of column inches allocated to agricultural news and the seven (7) other categories of news. This is further exemplified in the correlation matrix (Table 2).

Table 2. Correlation between column inches allocated to agriculture and other categories of news

\begin{tabular}{lllllllll}
\hline & Sports & Politics & Foreign & Business & Entertainment & Religion & Education & Agriculture \\
\hline Sports & 1 & & & & & & & \\
Politics & 0.079 & 1 & & & & & & \\
Foreign & 0.62 & 0.18 & 1 & & & & & \\
Business & 0.48 & 0.38 & 0.84 & 1 & & & & \\
Entertainment & 0.54 & 0.16 & 0.92 & 0.9 & 1 & & & \\
Religion & -0.63 & -0.44 & -0.92 & -0.9 & -0.86 & 1 & & \\
Education & -0.61 & -0.47 & -0.86 & -0.93 & -0.86 & 0.99 & 1 & \\
Agriculture & -0.2 & -0.15 & 0.2 & 0.52 & 0.5 & -0.15 & -0.23 & 1 \\
\hline
\end{tabular}

Table 2 showed a negative correlation between agriculture and sports news (-0.20), politics $(-0.15)$, religion $(-0.156$ and education $(-0.23)$. The more the latter categories of news were given more spaces in the newspaper, the less amount of space given to agricultural news. The results showed that more spaces were given to sports and politics by the newspaper. This also connotes that the Pointer newspaper showed more interest in sports and politics than agriculture. It should be emphasised that sports and politics cannot put food in the mouths of a hungry people. Wikipedia (2000) stated that agriculture news was surprisingly neglected in the media when compared to other issues such as politics, business, sports and adverts. In the national dailies, most of the agricultural reports addressed one type of controversy or the other and sometimes relate to market forces. Obinne (1994) noted that broad based agricultural information could enable farmers improve upon their environment and agricultural production activities. The mass media constituted the best source of knowledge for disseminating agricultural information to farmers because of the advantage of reaching a very wide audience at the same time.

3.2 Coverage of the Categories of Agricultural News in 2009

Table 3. Categories of agricultural news and percentage space allocated in 2009

\begin{tabular}{lccccccccccccc}
\hline Categories & Jan & Feb. & March & April & May & June & July & Aug & Sept & Oct & Nov & Dec & Grand Average \\
\hline Agronomy & 22.1 & -- & -- & -- & 18.34 & -- & -- & 10.43 & -- & 12.68 & 10.94 & 11.6 & 7.17 \\
Fisheries & 13.96 & -- & -- & -- & -- & 22.35 & 11.4 & 19.75 & 8.9 & 14.56 & 8.8 & 19.15 & 9.9 \\
Forestry and wildlife & -- & 16.16 & 21.69 & 25.23 & 17.34 & -- & 21.6 & 15.17 & -- & 13.34 & -- & 7.77 & 11.52 \\
Poultry & 25.79 & 18.28 & 17.74 & 28.1 & 42.48 & 52.48 & 17.37 & 25.94 & -- & 34.31 & 27.63 & 27.04 & 26.43 \\
Livestock & 9.85 & 13.88 & 24.2 & 27.74 & 21.84 & 25.17 & 10.17 & 18.36 & 18.6 & -- & 39.17 & 15.67 & 18.72 \\
Govt. policy on agriculture & 28.3 & 26.47 & 13.86 & 18.93 & -- & -- & 16.5 & 10.35 & 25.08 & 26.11 & -- & 18.77 & 15.36 \\
Commentaries & -- & 25.21 & 22.51 & -- & -- & -- & 22.96 & -- & 47.42 & -- & 13.46 & -- & 10.96 \\
Total & 100 & 100 & 100 & & 100 & 100 & 100 & 100 & 100 & 100 & 100 & 100 & 100 \\
\hline
\end{tabular}


Seven categories of agriculture news frequently reported by Pointer newspaper were identified. These were agronomy (crop), fisheries, forestry and wildlife, poultry, livestock, government policies on agriculture and commentaries on agriculture. The percentage column inches or space allocated to these categories of agricultural news was worked out for each month in 2009 (Table 3).

Table 3 showed that poultry had highest percentage column inches in 6 months (April, May, June, August, October and December) and grand average of $26.43 \%$. It was only in the month of September that poultry news was not reported. Livestock news (18.72\%), government policies on agriculture (15.36\%), and commentaries on agriculture $(10.96 \%)$ had highest percentage column inches allocation in two months. Agronomy (7.17\%), fisheries $(9.90 \%)$, and forestry and wildlife $(11.52 \%)$ were among the least reported agriculture news. Poultry news was frequently reported among the categories of agricultural news. This was attributed to the growing importance of the poultry industry in the state.

\section{Conclusion}

The coverage of any news item apparently portrays the importance attached to it. Sports, politics, religious, foreign, business, entertainment, and education news were frequently reported more than agriculture news. There was significant relationship between column inches allocated to agriculture news and other categories of news covered by the Pointer newspaper in 2009. Among the categories of agriculture news, poultry news was frequently reported than the others by the Pointer newspaper in 2009 . The study also provided a methodological approach to the measurement of news coverage by daily news papers.

Today, there is a strong need to boost agricultural production through mass media education, information and dissemination of agricultural technologies to farm families. The problem of illiteracy among farmers does not juxtapose the poor coverage of agricultural news by a state government owned newspaper like the Pointer. The Pointer newspaper should devote more space to agricultural news in order to enhance dissemination of agricultural information in the state.

\section{References}

Abbas, T., Pervez, M. A., Balal, R. M., Shehid, M. A., \& Bajwa, A. (2011). Mass Media has Significant Role to Play in Agiculture. Agri Hunt, pp. 1-5.

Agbamu, J. U. (2006). Essentials of Agricultural Communication in Nigeria (pp. 90-93). Lagos: Malthouse Press Limited.

Cater, I. (1991). Locally Generated Printed Materials in Agriculture: Experience from Uganda and Ghana. Education Research Report No.31. London: Department Report International Development. p. 35

Chambers, R. (1993). Challenging the Profession: Frontiers for Rural Development (p. 25). London: Intermediate Technology Publications.

Ekpere, J. A., \& Durant, T. J. (1986)). Agricultural Extension and Rural Sociology. In A. Youdeowei, F. O. C. Ezedinma \& O. C. Onazi (Eds.), Introduction to Tropical Agriculture (pp. 282-300). London: Longman Group Limited.

Ifenkwe, G. E. (2008). Assessment of Newspaper Advocacy for Rural Development and Environmental Education in Nigeria. Journal of Agricultural Extension, 12(2), 41-51.

Igbokwe, E. M., \& Enwere, N. J. (2001). Participatory Rural Appraisal in Development Research. Abuja: New Generation Books, pp. 12-14.

Korten, D. C. (1990). Getting to the $21^{\text {st }}$ Century: Voluntary Action and Global Agenda (p. 71). West Hartford: Conn Kumarian Press.

Laogun, E. A. (2005). Extension Teaching Learning Process and Extension Methods. In S. F. Adedoyin (Eds.), Agricultural Extension in Nigeria (pp. 201-207). Ilorin : Agricultural Extension Society of Nigeria.

Madukwe, M. C. (2006). Delivery of Agricultural Extension Services to Farmers in Developing Countries. S \& T Issues, CTA \& S\& T, pp. 1-4.

Mody, B. (1991). Designing Message for Development Communication (p. 253). California : Sage Publication.

Moemeka, A. A. (1990). Mass Media Communication and Rural Dwellers: Towards the Effectiveness of Development Message. In L. Oso \& L. Adebayo (Eds.), Communication and Rural Development in Nigeria (pp. 52-75). Abeokuta : Millenium Investment Ltd.

Obinne, C. P. (1994). Fundamentals of Agricultural Extension (p. 45). Enugu: ABC Publishers. 
Okorie, N., \& Oyedepo, T. (2011). Newspaper Reportage and its Effects Towards Promoting Agricultural Development in Nigeria. Journal of Media and Communication Studies, 3(2), 27-32.

Okunade, E. O. (2007). Effectiveness of Extension Teaching Methods in Acquiring Knowledge, Skill and Attitude by Women Farmers in Osun State. Journal of Applied Sciences Research, 3(4), 282-286.

Oladeji, J. O. (2011). Farmers' Perception of Agricultural Advertisement in Nigerian Newspapers in Ibadan Municipality, Oyo State, Nigeria. Journal of Media and Communication Studies, 3(3), 97-101.

Olowu, T. A., \& Yahaya, M. K. (1993). Nigerian Journalists Attitude Towards Coverage of Rural Development News. The Nigerian Journal of Rural Extension and Development, 1 (2 and 3), 39-48.

Ovwigho, B. O., \& Ifie, P. A. (2009). Principles of Youth Development in Africa (pp. 157-158). Benin-City: Ethiope Publishing Corporation.

Pretty, J. N., \& Vodouche, S. D. (1997). Using Rapid or Participatory Rural Appraisal. In B. E. Swanson (Eds.). Improving Agricultural Extension: A Reference Manual (pp. 47-54). Rome: Food and Agriculture Organization.

Rogers, E. M. (2003). Diffusion of Innovations (p. 131). New York: The Free press.

Singh, M. P., \& Kumah, B. (1977). Analysis of the Space Provided for Agricultural Information in Leading Newspapers of Bihari. Indian Journal of Extension Education, 3(3\& 4), 27-33.

Sitton, S., Terry, R., \& Key, J. (2001). A Content Analysis of Oklahoma's Two Largest Newspapers 1998 Coverage of Oklahoma Swine Concentrated Animal Feeding Operations. A Paper Presented to the Southern Association of Agricultural Scientists Agricultural Communication Section, Fort Worth. January, 2001.

Van den Ban, A. W., \& Hawkins, H. S. (1996). Agricultural Extension (p. 96). London: Blackwell Sciences Ltd.

Wikipedia. (2000). The Economy of Nigeria (on-line). Retrieved August 2006, from $\mathrm{http} / \mathrm{www}$.enwikipedia.org/wik/economy of Nig.

Williams, S. K. T., Fenley, J. M., \& Williams, C. E. (1984). A Manual for Agricultural Extension Workers in Nigeria (pp. 68-88). Ibadan : Les Shyradan. 